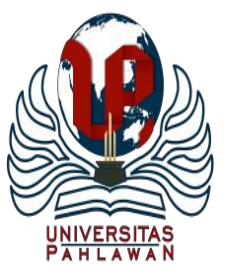

Edukatif : Jurnal Ilmu Pendidikan Volume 2 Nomor 2 Tahun 2020 Halm 128-133

EDUKATIF: JURNAL ILMU PENDIDIKAN

Research \& Learning in Education

https:/ledukatif.org/index.php/edukatif/index

\title{
Analisis Kebijakan Dan Pengelolaan terkait Peserta Didik Di Sekolah Dasar
}

\author{
Faridatul Umi ${ }^{1}$, Sufyarma Marsidin ${ }^{2}$, Ahmad Sabandi $^{3}$ \\ Universitas Negeri Padang, Sumatera Barat, Indonesia ${ }^{1,2,3}$ \\ E-mail : umifaridatul12@gmail.com ${ }^{1}$ sufyarma@gmail.com ${ }^{2}$ sabandi@fip.unp.ac.id ${ }^{3}$
}

\begin{abstract}
Abstrak
Artikel ini menganalisis kebijakan dan pengelolaan pendidikan mengenai peserta didik di sekolah dasar. Penelitian yang dilakukan melalui kajian pustaka. Pengelolaan peserta didik ialah penataan seluruh aktifitas yang berhubungan dengan peserta didik dari awal masuknya peserta didik hingga keluarnya peserta didik dari lembaga pendidikan tertentu. Tujuan pengelolaan peserta didik adalah untuk mengatur seluruh aktivitas yang dilakukan oleh peserta didik agar kegiatan pembelajaran berjalan dengan baik. Seluruh aktifitas pengelolaan peserta didik harus memberikan dampak positif, bermanfaat serta sesuai dengan tujuan pendidikan. Dasar pengelolaan peserta didik ini diatur dalam UUD 1945 alinea keempat, UUD 1945 pasa 31 ayat 1-5, dan UU No. 20 Tahun 2003.
\end{abstract}

Kata kunci: pengelolaan, peserta didik, sekolah dasar

\begin{abstract}
This article analyzes education policy and management regarding students in primary schools. Research conducted through literature review. Student management is the arrangement of all activities related to students from the initial entry of students to the departure of students from certain educational institutions. The purpose of student management is to manage all activities carried out by students so that learning activities run well. All management activities of students must have a positive, beneficial and in accordance with the objectives of education. The basis of the management of these students is regulated in the 1945 paragraph of the fourth paragraph, the 1945 Constitution of paragraph 31 paragraph 1-5, and Law no. 20 of 2003.
\end{abstract}

Keywords: management, student, primary school

Copyright (c) 2020 Faridatul Umi, Suryarma Marsidin, Ahmad Saband i

$\triangle$ Corresponding author :

Address :

Email : umifaridatul12@gmail.com

ISSN 2656-8071 (Media Cetak)

Phone :

ISSN 2656-8063 (Media Online)

DOI: https://doi.org/10.31004/edukatif.v2i2.114 


\section{PENDAHULUAN}

Pendidikan adalah salah satu usaha untuk mencerdaskan kehidupan bangsa. Proses pendidikan yang baik akan melahirkan manusia yang berkualitas serta memiliki potensi untuk memajukan bangsa dan negara. Untuk mewujudkan tujuan pendidikan sebagaimana yang tertuang dalam pembukaan UUD 1945 memerlukan pengelolaan dari berbagai aspek, salah satunya yaitu pengelolaan peserta didik. Pengelolaan berarti kegiatan yang dilakukan didasarkan atas aturan untuk mencapai sebuah tujuan (Suminar, 2018). Sedangkan peserta didik adalah individu yang terdaftar mengikuti pendidikan pada sebuah lembaga pendidikan untuk mengembangkan potensi dirinya (Annas, 2017). Jadi pengelolaan peserta didik adalah kegiatan yang dilakukan berhubungan dengan peserta didik dari awal masuknya peserta didik hingga keluarnya peserta didik dari lembaga pendidikan tertentu.

Pengelolaan peserta didik merupakan bagian dalam pengelolaan pendidikan. Nyatanya saat ini terdapat fakta bahwa sistem pengelolaan peserta didik masih berbentuk konvensional yang lebih menitikberatkan pada perkembangan kognitif semata serta kurangnya kesempatan bagi peserta didik untuk mengembangkn kreativitas serta bakat yang dimilikinya. Seperti yang kita ketahui bersama, kreativitas yang dimiliki oleh seseorang merupakan kebutuhan mendasar manusia. Perkembangan peserta didik yang baik ialah perubahan diri yang sesuai antara fisik maupun mental peserta didik itu sendiri. Penyelanggaraan pendidikan saat ini hendaknya mengupayakan pemberian pelayanan khusus kepada peserta didik untuk mengembangan segala kreativitas serta bakatnya serta diarahkan untuk menjadi individu yang lebih baik.

Pendidikan tidak akan bisa terlepas dari pengajaran. Kegiatan pengajaran melibatkan peserta didik sebagai penerima materi ajar sesuai dengan UU No. 20 tahun 2003, yaitu peserta didik bisa mengembangkan potensi yang ada pada dirinya secara aktif untuk memiliki kesehatan spiritual keagamaan, pengendalian diri, kecerdasan, akhlak mulia, serta keterampilan yang diperlukan dirinya, masyarakat, bangsa, dan negara.

Peserta didik menjadi subjek pendidikan karena kepada peserta didiklah proses belajar dilakukan dengan menerapkan bahan ajar yang dipersiapkan guru. Peserta didik memiliki ciri khas tersendiri serta memiliki berbagai perbedaan, setiap peserta didik unik berbeda dengan yang lain. Potensi yang dimiliki setiap peserta didik tidak dapat disamakan. Para pendidik harus memahami serta menghargai perbedaan pada setiap peserta didik. Keunikan yang terdapat pada peserta ddik merupakan suatu persoalan tersendiri bagi dunia pendidikan yang harus diketahui serta diselesaikan karena pengelolaan peserta didik mutlak harus diperhatikan. Sebab itu, pengelolaan peserta didik harus dapat dipahami oleh guru maupun tenaga pendidik lainnya.

\section{METODE}

Penelitian ini menggunakan studi kepustakaan (library research) sebagai metode penelitiannya. Pembahasan penelitian diperoleh 
dari berbagai literatur dengan kegiatan mengumpulkan, memadukan, menganalisis serta mengkritisi hasil bacaan.

Studi kepustakaan identik dengan pengumpulan data dari berbagai sumber bacaan. Buku, jurnal, maupun artikel ,merupakan bahan bacaan yang menjadi sumber data dalam penelitian ini.

\section{HASIL DAN PEMBAHASAN}

\section{Pengertian Pengelolaan Peserta Didik}

Pengelolaan atau manajemen merupakan sebuah kegiatan yang dilakukan secara mandiri maupun bersama-sama berdasarkan aturan tertentu untuk mencapai suatu tujuan. Sementara itu peserta didik atau siswa diartikan sebagai anak yang sedang sekolah atau seseorang yang mendapatkan pendidikan dari suatu lembaga pendidikan. Peserta didik menjadi objek pada penyelenggaraan pendidikan. UU No 20 Tahun 2003 menjelaskan peserta didik merupakan seseorang yang mempunyai usaha untuk meningkatkan kualitas diri dengan mengikuti pembelajaran pada suatu lemabaga pendidikan.

Dari berbagai pendapat yang telah dijabarkan, dapat disimpulkan peserta didik merupakan seseorang yang berkeinginan mengembangkan potensi yang ada pada dirinya dengan kegiatan belajar pada suatu jenjang atau tingkat tertentu yang menjadi objek utama dalam penyelengaraan pendidikan lembaga tersebut.

Pengelolaan peserta didik ialah penataan seluruh aktifitas yang berhubungan dengan peserta didik, dari awal masuknya peserta didik hingga keluarnya peserta didik dari lembaga pendidikan tertentu. Pengelolaan peserta didik berguna dalam membantu tumbuh kembang peserta didik melalui pendidikan pada suatu sekolah. Pengelolaan tersebut dapat dilakukan dengan empat fungsi pengelolaan yaitu perencanaan, pengaturan, pelaksanaan, dan pengontrolan (Junaidi, 2016).

\section{Tujuan dan Fungsi Pengelolaan Peserta Didik}

Pengelolaan peserta didik secara umum bertujuan mengatur seluruh aktivitas peserta didik supaya aktivitas yang dilakukan oleh peserta didik dapat mendukung setiap kegiatan pembelajaran yang dilakukan (Taqwa, 2016). Kegiatan pembelajaran yang berjalan dengan baik dan teratur dapat memberikan pengaruh postif dalam usaha mencapai tujuan sekolah serta tujuan pendidikan. Sedangkan tujuan khusus pengelolaan peserta didik yaitu dijabarkan sebagai berikut:

1. Mengembangkan aspek kognitif, afektif serta psikomorotik yang dimiliki peserta didik

2. Memberi kesempatan agar peserta didik dapat mengembangkan serta menyalurkan kecerdasan, bakat, serta minat yang dimilinya

3. Menyalurkan harapan, spirasi serta dapat memenuhi kebutuhan peserta didik

Terpenuhinya ketiga tujuan di atas dapat memberikan harapan agar peserta didik mencapai kebahagian serta kejesahteraan hidup dengan tercapainya tujuan hidup serta cita-cita yang dimiliknya. Secara universal pengelolaan peserta didik sebagai wadah bagi peserta didik secara optimal untk dapat mengebangkan segala potensi yang dimilikinya baik dari segi individual, sosial maupun dari segi aspirasi. Sedangkan fungsi pengelolan peserta didik secara khusus yaitu: 
131 Analisis Kebijakan Dan Pengelolaan terkait Peserta Didik Di Sekolah Dasar - Faridatul Umi, Sufyarma Marsidin, Ahmad Sabandi

1. Fungsi untuk mengembangkan potensi yang dimilki oleh setiap individu, meliputi potensi kecerdasan dan bakat

2. Fungsi pengembangan sosial

3. Fungsi penyaluran pendapat serta keinginan peserta didik

4. Fungsi pemenuhan kebutuhan peserta didik

\section{Prinsip Pengelolaan Peserta Didik}

Prinsip pengelolaan peserta didik yaitu aturan yang dipegang serta dipedomani dalam melakukan kegiatan pengelolaaan peserta didik. Prinsip pengelolaan tersebut yaitu:

1. Pengelolaan peserta didik dipandang komprehensif dari pengelolaan sekolah mendukung tujuan pengelolaan secara keseluruhan.

2. Seluruh aktifitas pengelolaan harus sesuai dengan tujuan pendidikan. Segala jenis kegiatan yang dilakukan peserta didik diupayakan untuk mendidik.

3. Kegiatan peserta diidik hendaknya dapat mempersatukan setiap peserta didik yang memiliki background yang beragam.

4. Pengelolan peserta didik harus menjadi wadah bimbingan bagi mereka

5. Pengelolaan peserta didik harus mampu mendorong kemandirian diri

6. Segala sesuatu yang diupayakan dalam pengelolaan didik haruslah memberikan dampak positif dan bermanfaat bagi kehidupan.

\section{Pendekatan Pengelolaan Peserta Didik}

1. Pendekatan kuantitatif

Pendekatan ini bertujuan agar peseta didik bisa melaksanakan tuntutan lembaga pendidikan seperti kehadiran, dan menyelesaikan tugas yang diberikan sehingga peserta didik menjadi mampu.

2. Pendekatan kualitatif

Pendekatan ini mengupayakan agar peserta didik nyaman dan senang sehingga bisa belajar dengan baik. Selain itu penyedian iklim yang kondusif dan meyenangkan juga menjadi tujuan dari pendekatan ini.

3. Pendekatan terpadu

Pendekatan ini adalah gabungan dari kedua pendekatan sebelumnya. Peserta didik menyelesaikan tugas dari lembaga pendidkan, dan lembaga pendidkan menyediakan suasana yang menyenagkan untuk menyelesakan tugas tersebut (Taqwa, 2016).

\section{Ruang Lingkup Pengelolaan Peserta Didik}

Ruang lingkup pengelolaan peserta didik yaitu :

1. Perencanaan peserta didik

Hal-hal yang dilakukan yaitu: 1) menganalisis kebutuhan peserta didik, 2) melakukan penerimaan melauli panitia penerimaan, 3) melakukan seleksi peserta didik, 4) orientasi, dan 5) pembagian kelas.

2. Mengatur kehadiran dan ketidakhadiran

Kehadiran sangat penting agar terjadi interaksi dalam proses pembelajaran. Ketidakhadiran akan membuat proses belajar terhambat. Ketidakhadiran ini terbagi menjadi 
132 Analisis Kebijakan Dan Pengelolaan terkait Peserta Didik Di Sekolah Dasar - Faridatul Umi, Sufyarma Marsidin, Ahmad Sabandi

ketidak hadiran karna lingkugan keluarga, diri sindiri, sekolah ataupun masyarakat atau biasanya dikenal dengan istilah alfa, izin dan sakit.

3. Pecatatan dan pelaporan

Pencatatan dan pelaporan peserta didik dimulai dari masuk sampai lulus. Adapun tujuannya yaitu untuk pertanggungjawaban kepada pihak tertentu yang ingin mengetahui perkembangan peserta didik. Pencatatan dan pelaporan ini berupa buku induk siswa, buku klepper, daftar presensi, buku raport, buku legger, dan buku catatn pribadi peserta didik (Rahmi, 2014).

4. Pembinaan

Berbagai layanan pembinan peseta didik yaitu berupa layanan bimbingan konseling, perpustakaan, layanan kantin, UKS, transportasi dan asrama. Semua layanan tersebut tersedia untuk penunjang pengelolaan peserta didik.

5. Evaluasi kegiatan peserta didik

Evaluasi kegiatan dilakukan untuk melihat perkembangan peserta didik baik itu melalui pengamatan, wawancara, maupun tes.

6. Kelulusan dan alumni

Kelulusan merupakan proses akhir dari pengelolaan peserta didik yang menandakan bahwa peserta didik telah menyelesaikan program pendidikannya yang kemudian namanya kan terdaftar sebagai alumni.

7. Mutasi

Mutasi adalah perpindahan peserta didik dari suatu lembaga pendidikan ke lembaga pendidikan lainnya (Alwi, Ramadani,

Suhanir, Safira, \& Herma, 2018).

\section{KESIMPULAN}

Pengelolaan peserta didik ialah aturan segala aktifitas yang dilakukan oleh peserta didik, selama berada pada suatu lembaga pendidikan. Pengelolan peserta didik dapat dipergunakan untuk membantu perkembangan serta pertumbuhan peserta didik secara optimal melalui proses pendidikan di sekolah. Tujuan pengelolaan ini adalah untuk mengatur aktifitas peserta didik agar menunjang kegiatan penbelajaran di sekolah. Fungsi pengelolaan peserta didik adalah agar peserta didik dapat mengembangakan diri secara maksimal pada suatu lembaga pendidikan.

\section{DAFTAR PUSTAKA}

Alwi, B. M., Ramadani, S., Suhanir, Safira, Z., \& Herma, T. (2018). Manajemen Peserta Didiik Pada Taman Pendidikan Anak Usia Dini Do ' a Ibu. Indonesian Jural of Early Childhood Education, 1(1), 53-62.

Annas, A. N. (2017). Manajemen Peserta Didik Berbasis Kecerdasan Spiritual Pendidikan Islam. Jurnal Manajemen Pendidkan Islam, 5(April), 132-142.

Junaidi, J. (2016). Pelaksanaan Manajemen Peserta Didik Pada Man Beringin Kota Sawahlunto. Al-Fikrah: Jurnal Manajemen Pendidikan, 3(1), 37.

Rahmi, N. (2014). Persepsi Guru Tentang Manajemen Peserrta Didik SDN Gugus II Kec. Lubuk Sikarah Kota Solok. Jurnal Administrasi Pendidikan, Bahana Manajemen Pendidkan, 2(1), 528-534.

Suminar, W. (2018). Manajemen Peserta Didik Untuk Meningkatkan Pretasi Siswa pada Madrasah Aliyah Negeri (MAN) Pacitan. 
133 Analisis Kebijakan Dan Pengelolaan terkait Peserta Didik Di Sekolah Dasar - Faridatul Umi, Sufyarma Marsidin, Ahmad Sabandi

Muslim Heritage, 2(2), 389.

Taqwa. (2016). Pendekatan manajemen peseta didik. Journal of Islamic Education Management, 1(1), 48-55. 